\title{
Power in office: presidents, governments, and parliaments in the institutional design of contemporary democracies
}

\section{Giuseppe leraci ${ }^{1}$ (C)}

Accepted: 18 September 2020 / Published online: 28 October 2020

(c) The Author(s) 2020

\begin{abstract}
The institutional design of democratic regimes has attracted much attention from a legal and political perspective, because it affects the actual distribution of power among political actors and the effectiveness of their decisions. The article advances a classification of the democratic institutional design, with particular reference to the triangular interactions among Presidents, Governments, and Parliaments. Moving from the assumption that the arrangements among these three top political institutions identify the main patterns of the democratic government, the distinction among Parliamentary, Presidential, and Semi-Presidential systems set by the constitutional law is rejected and a new classification schema is advanced. In this new perspective, the institutional design of democracy consists of the institutional roles of authority, procedural resources attached to them and arenas of confrontation among the roles.
\end{abstract}

Keywords Presidents · Governments · Parliaments · Institutional design · Democracy

\section{JEL Classification $\mathrm{H} \cdot \mathrm{H} 11$}

\section{Introduction}

Contemporary political science has established itself on methodological and conceptual bases which have marked its distance from the formal and legal analysis of political institutions. Nonetheless, following or adapting the seminal work by Duverger $(1980 ; 1986)$ the triangular relationship among parliaments, presidents and governments has sometimes been reduced to three ideal-types: the Parliamentary, the Presidential, and the Semi-Presidential outlined by the constitutional scholars. ${ }^{1}$ This classification generates some ambiguities which political scientists have been

\footnotetext{
${ }^{1}$ For a reappraisal of Duverger's concept of semipresidentialism, see Bahro, Bayerlein and Veser (1998).

Giuseppe Ieraci

Giuseppe.Ieraci@dispes.units.it

1 Università degli Studi di Trieste, Trieste, Italy
} 
dealing with for a long time. If we took into consideration the parliamentary system, for instance, and its legal definition as a model in which the government (or executive) depends on the parliament (or legislature) we would be led to the unsatisfactory conclusion that the English cabinet model does not differ in any significant way from the Italian or French IV Republic parliamentary models, notwithstanding that the former has a monocratic structure in which the Prime Minister holds a prominent position in the Cabinet, while the latter have a collegial executive structure where the President of the Council of Minsters is a primus inter pares.

Similar inconsistencies can be spotted in the long lasting debate over the mixed pattern of government, labeled semi-presidentialism and known as a generalization of the French V Republic's case. The subsequent attempt to force into it any other case resembling formally that ideal-type has raised several problems. Indeed, many cases with an elective President and a parliamentary cabinet differ drastically from the French ideal-type when the concrete distribution of powers among president, parliament and government is taken into account. Finally, presidentialism as a formalization of the U.S. constitutional model overlooks the basic differences in the application of the same constitutional principles in other contexts.

After a brief critical review of some attempts to classify the institutional systems of democracy, a new classification based on a multidimensional approach will be introduced. It will be argued that democracies vary according to the type of institutional roles of authority designed, to the actual distribution of procedural resources among them, and finally to the features of their relationships in the arenas of institutional confrontation. The advanced classification identifies four arenas of institutional confrontation where the relationships among the roles of authority depend on the distribution of some given procedural resources. The method of investigation here introduced implies a quantitative analysis of the distribution of procedural resources among the roles of authority, together with the identification of the major dimensions along which they should be evaluated.

\subsection{Some attempts to classify democratic regimes}

The need for a reappraisal of the classification of democratic regimes was triggered years ago by the debate on presidentialism versus parliamentarism, and on the relative performance of these two regimes. Linz distinguished parliamentarism and presidentialism pointing out their different kind of legitimacy. In the former the parliament is the only institution democratically legitimated, while the presidential systems are based on a «double democratic legitimacy» directed towards the parliament and the elective presidency at the same time (Linz 1994). Lijphart (1999) underlined that in a parliamentary system, the prime minister and the cabinet depend on the legislature's confidence, while in presidential systems the presidents are popularly elected. Moreover, in parliamentary systems the executives are collegial bodies, while in presidential systems they exhibit «one-person» and non-collegial traits. Lijphart combined these dichotomous criteria yielding eight possible models, only 
two of which are pure (parliamentarism and presidentialism) while the remaining six are hybrids derived from the two pure models. ${ }^{2}$

Similarly, Stepan and Skach distinguished among «pure presidentialism» and «pure parliamentarism». While the former is a system of «mutual independence» between the parliament and the head of the executive, the latter is a system of «mutual dependence», in which the head of the executive needs the support of a parliamentary majority and holds, sometimes with the head of the state, the power to dissolve the parliament and to call new elections (Stepan and Skach 1994). Sartori recognized the difficulty to identify parliamentary systems, because they can hardly be reduced into an homogenous class while in presidential systems the head of the state (the president) gets the position through popular election, can not be removed by the parliament during his mandate and directs the government or the governments nominated by himself (Sartori 1994a).

In a very influential work,Shugart and Carey (1992) classified as presidential government any system based on the direct election of the head of the executive, to whom some legislative powers are constitutionally guaranteed. In the presidential government, the mandates of the head of the executive and of the legislature have fixed durations, they are constitutionally separated, and the nomination and the direction of the government are entirely in the hands of the elective head of the executive. Shugart and Carey's typology deserves attention, because of its multidimensional character and because they fully developed the approach based on the 'index of presidential power' already sketched by Duverger (1980). Nonetheless, some solutions suggested by Shugart and Carey do not seem entirely convincing. For instance, in any presidential model the cabinet is the «President's executive» by definition, and consequently using the separation of the survival of the cabinet from the assembly as a criterion to identify the presidential system is merely tautological. Consequently Shugart and Carey's typology does not enlighten the crucial dimension of the relation between president and assembly, with regard to which the president's authority may vary to a great extent from case to case. Shugart and Carey took into consideration mainly the president's legislative veto power omitting to evaluate the complete array of constitutionally guaranteed powers which the president may employ in his relation with the legislature. ${ }^{3}$ Finally, it has to be noted that the French V Republic and the Weimar Republic, both characterized by a strong popularly elective presidency, are very different from the homologous semi-presidential regimes of Finland, Ireland, Austria and Portugal, or from the newly established regimes in Central and Eastern Europe, and therefore it is possible to identify more regime types in a single class. ${ }^{4}$

\footnotetext{
2 Vatter (1999) applied Lijphart's classification to the analysis of the relationship between political institutions and direct democracy in the OECD countries.

3 These properties of the presidential system have been tackled somewhere else. See Mainwaring e Shugart (1997). For a critical review of Shugart and Carey's classification, see Sartori (1994b).

4 Contra see Elgie $(1999 ; 1998 ; 1997)$ who does not consider it necessary to disaggregate into different types the original class of semi-presidential regimes. Elgie (1998) classifies democratic regimes resorting to two criteria, the type of election of the head of state and of the head of government, either direct or indirect, and their term in office, either fixed or flexible. On these bases, Elgie identifies parliamentary, semi-presidential and presidential regimes, with the addition of the unique cases: the Swiss directorate and the regime based on the direct election of the premier adopted in Israel during 1996-2001, following the 1992 reform of the Fundamental law.
} 


\subsection{Indexes of presidential powers. some criticisms and a new perspective}

The institutional frameworks exhibited by contemporary democracies vary according to morphological and relational criteria, the former referring to the institutional roles embedded in a given pattern, while the latter referring to the degree of reciprocal influence or procedural powers among these roles in the decision-making circuit. The classification which I will introduce later will use both criteria. Some pitfalls of the existing classifications derive from the unrecognized distinction between morphological and relational properties of the regimes as is evident in the Indexes of Presidential Powers (IPP) so often used in literature. ${ }^{5}$

The IPP are normally based on the original intuition of Duverger $(1978 ; 1980)$ that the presidential powers could be counted and subsequently weighted to compare regimes with an elective President. The methodologies normally applied consist of checklists of constitutional powers which are weighed and summed to determine a score or index. These methodologies suffer two major pitfalls. Firstly, they are not analytical and do not take into consideration the underlying dimensions of the presidential powers listed. They are summations of powers in single cumulative scores, which do not discriminate between the relational dimension of the listed powers, i.e. either the President-Parliament, the President-Government, or the Government-Parliament. Consequently, presidents placed in different institutional settings may hence score equal although it does make a difference whether they derive their 'strength' from powers concerning their relationship with the legislature or with the government. Secondly, the scores attributed to the constitutional powers change, some authors assigning equal scores to each power and others ranking them according to their assumed relevance.

Elster (1997, 226-228) criticized the checklist methodology and the IPP approach because through scoring the formal «constitutional powers» it neglects the «de facto powers» which may be conferred to the president by their direct and popular election. Moreover, the IPP approach would not take into consideration the possibility that the powers enjoyed by the presidents might go beyond those actually conferred by the constitution. Finally, Elster argued that the scores assigned to the powers were «irremediably arbitrary», ${ }^{6}$ even in the case of the methodologies applied by Shugart and Carey (1992), Frye (1997), and Siaroff (2003). ${ }^{7}$ Shugart and Carey did not distinguish between legislative (President-Parliament relation) and executive powers (President-Government relation), besides they attributed variable scores (from 1 to 4 ) to such powers omitting to clarify the criteria for the attribution. Similarly, Frye's twenty-seven point checklist mixed together ten appointment powers of postcommunist presidencies and some legislative powers, with some distorting effects of the scoring. ${ }^{8}$ Frye (1997) ranked the presidential powers from 1 (exclusive attribution) to 0.375 (power sharing), therefore confusing in a synthesis index various relational aspects of the institutional arrangement (namely, the power capacity of the

\footnotetext{
5 A complete and critical review of the IPP is offered by Zulianello (2011).

6 Elster's criticisms were mainly referring to McGregor (1994).

7 For an application of Siaroff's checklist method and IPP, see Van Cranenburgh (2008).

8 Metcalf $(2000,664)$ argued that Frye's checklist misrepresented the legislative capacities of the presidencies in comparison with their executive capacities.
} 
presidency and its relative autonomy vis á vis other institutions). ${ }^{9}$ Finally, although Siaroff $(2003,293-303)$ did not weigh the presidential powers and chose to dichotomize their measurement ( $1=$ power capacity; $0=$ power incapacity), he still adopted a single or one-dimensional checklist of nine presidential powers in which no attention is paid to whether the powers derive from the modality of the election of the president (popularly elected or not), or from their executive or legislative capacities and attributions.

Jon Elster's skepticism was based on sound reasons, but nevertheless it could be overcome. His last point (the arbitrary character of some measurements of the presidential powers) was fully recognized by some scholars (Ieraci 2003; Siaroff 2003) who simply dichotomized $(1 ; 0)$ the measurements. This solution assumes that what would make a role of institutional authority «strong» and another «weak» is not the control over some specific constitutional powers, or simply the modality of the election but rather the complete array of institutional capacities at its disposal. Such capacities enhance the likelihood that a given role of authority will be decisive and effective in the institutional circuit and in the network of relations with the other roles. Secondly, the checklist approach is too basic to prove satisfactory. At its best, it generates a blurred picture which does not allow to discern the specificities of each presidential arrangement. With regard to which other institutional roles is the presidency strong; the executive or the legislative, or both? The IPP obtained through the checklist approach provides a possible synthesis, but not an answer to this question.

\subsubsection{A new classification of the democratic regimes}

Duverger $(1980,161)$ underlined that in semi-presidential regimes the president («elected by popular vote») possesses considerable powers. All the definitions above reviewed underline the particular configuration of pure presidentialism, which is the notable reciprocal autonomy of parliament and executive. On the contrary, the pure parliamentarian type exhibits a considerable degree of mutual dependency (or integration) between parliament and executive. Nonetheless, these definitions do not solve some ambiguities. Firstly, there are some parliamentary democracies where the Prime Minister occupies a dominant role in the cabinet and in the legislature, and where he/she acts almost as an elective president. Secondly, there are some mixed models labeled semipresidentialism, where an elective president and a parliamentary government coexist, although both strong (French V Republic and Republic of Weimar) and weak presidencies (Finland, Ireland, Austria and Portugal) can be found in this class. Thirdly, even among the presidential systems, there are cases of weak and strong directly elected presidents to such an extent that the suspicion begins to be aroused that the popular direct election as a criterion might not suffice on its own for the identification of all the presidential types.

\footnotetext{
9 This aspect is further developed, see infra the paragraph dedicated to the analysis of «procedural resources».
} 


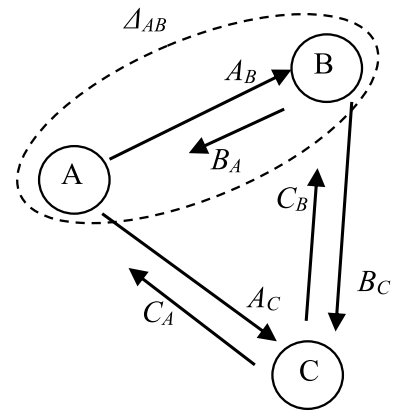

Legenda:

A, B, C: Institutional Roles;

$A_{\mathrm{B}}, B_{\mathrm{A}}, C_{\mathrm{A}}$, etc.: Procedural resources (i.e. $A_{\mathrm{B}}$ : Procedural resources of A versus $\mathrm{B})$;

$\leftarrow$ : Vectors of the Relation;

$\triangle_{A B}$ : Arena of the institutional confrontation (of A and B)

Fig. 1 A Morphological and Relational Approach to the Assessment of the Strength of the Institutional Roles

With regard to the problems involved by the classification of presidential systems, the perspective adopted by Shugart and Carey (1992) seems promising because it focuses on the «constitutionally guaranteed legislative powers» held by the elective presidents. Actually, both in the case of presidentialism and of parliamentarism the powers at the disposal of the executive and of the legislative can greatly vary. These non homogeneous distributions of «constitutionally guaranteed powers» point out the relevance of the relationships between the institutional roles, or rather the need for an analysis of the procedural resources held by the institutional actors and of their interplay. Moreover, the development of a similar approach may help in overcoming the ambiguity of the semi-presidential system in which the president enjoys «considerable powers» (Duverger 1980), by identifying such powers and allocating them to the three institutional roles of authority involved in the interplay (president, parliament, and government). If, as stated above, the semi-presidential systems may vary from cases with strong presidents to cases with weak presidents, what are the powers formally guaranteed or practically recognized to them? What are the powers either «constitutionally guaranteed» or practically recognized to parliaments, governments and presidents in their mutual relationships?

Attention should be directed both to the morphological and relational properties of the democratic regimes (see Fig. 1), which hence imply:

1. The identification of the institutional roles of authority. This is the first step in any classification of the regime types, although some scholars have left it implicit. This identification is crucial for analytical purposes, because it is a priority for the measurement of the powers of the roles with regard to the underlying relational dimensions.

2. The attribution of procedural resources to such roles. In an institutional setting, the power to take various courses of action and counter-action is provided by constitutional attributions and/or de facto powers, which the incumbents may exploit in their interactions. These constitutional attributions and/or de facto powers are procedural and their control is in itself a source of power and influence.

3. The identification of the arenas of the institutional confrontation. This is an aspect often neglected by most of the circulating classifications of the democratic 
Table 1 Typology of the Democratic Executives based on the Individual Roles of Authority

\begin{tabular}{llll}
\hline & \multicolumn{2}{l}{ Individual roles of Authority } & \\
\cline { 2 - 3 } & $\begin{array}{l}\text { Head of the Government } \\
(\text { HG })\end{array}$ & $\begin{array}{l}\text { Head of the State } \\
(\text { HS })\end{array}$ & \\
\hline 1 & YES & YES & Dual executives \\
2 & NO & YES & Monocratic (one-person) executives \\
3 & YES & NO & Collegial; acephalous executives \\
4 & NO & NO & \\
\hline
\end{tabular}

institutional settings. The procedural resources (2) attached to the institutional roles (1) should be evaluated and measured according to the specific contexts or relational dimension of application (i.e. Parliament-Government, Parliament-President, President-Government), rather than jumbled together. These complex networks of relations generate specific institutional arenas where the incumbents of the roles face each other using the resources and the formal capacities at their disposal. In the arenas of confrontation, the powers (i.e.: procedural resources) attached to each role can be conceived as vectors and can be measured as such.

\subsubsection{Institutional roles}

The roles of authority located in the democratic regime are attributed to specific actors, who emerge from the political competition. In presidential regimes the executive (normally controlled by a president directly elected by the people) is external and separate from the parliament, while in parliamentary regimes the executive is fully integrated with the parliament. In his classification Loewenstein $(1957,73)$, for instance, identifies two dominant models, the parliamentary and the presidential. In the former, parliament and government reach a equilibrium through integration and a limited degree of reciprocal independence, while in the presidential model parliament and government (i.e. presidential executive) are separated and «constitutionally forced» to cooperate. In this second pattern, the two institutions enjoy a considerable degree of reciprocal independence. Likewise, Steffani (1979; 1983) distinguishes the parliamentary and the presidential systems according to the degree of integration or cooperation between parliament and government. In the parliamentary systems, government and parliament are integrated and it is hard to distinguish the action of one from the other, the government acts through legislative decisions and the parliament is able to work because of the government majority or support. In presidential systems, parliament and government (i.e. the presidential executive) are independent and their relationship is cooperative.

These classifications are founded on the implicit distinction between «collegial roles of authority», such as Parliament $(\mathrm{P})$ and Government $(\mathrm{G})$, and «individual roles of authority», such as Head of State (HS) and Head of the Government (HG). 
The combinations of collegial and individual roles of authority in democracy are logically displayed in Table 1.

Starting from the individual roles (HS and HG), there are in a democracy four possible different combinations of them, as exemplified by Table 1 . True «dual executives» (combination 1) imply the presence of both a HG and a HS, the «one-person» or «monocratic executives» (combinations 2 and 3 ) exclude one of the two, and finally in the «collegial» or «acephalous executives» (combination 4) there is neither a HG nor a HS. If the monocratic executives do not present interpretative ambiguities, the collegial and a-cephalous executives are very rare, and the only historical cases to be recorded are the Uruguayan colegiado in the 1950's and the collegial executive of Cyprus according to the 1960 Constitution (Shugart and Carey 1992).

Dual executives are very common among contemporary democratic regimes, and they are known as «semi-presidential regimes». In some formally semi-presidential democracies (i.e. in the Austrian and the Irish cases) a directly elected HS plays only a marginal role in the political game, either because the procedural resources at it disposal have been neutralized through the years or because they are very limited and negligible. Therefore, the typologies which identify the semi-presidential regimes with the direct election of the HS, such as those put forward by Elgie (1998) and by Fabbrini and Vassallo (1999), classify as identical a plurality of cases where the elective HS has quite a different impact in the political process.

Dual executives cannot be reduced to a single type and, following Blondel (1984, 75), it will be assumed that they are identified when two roles and no more share the current business of the government. Usually one of these two roles is played by a HS, either a monarch or a president. Consequently, the cases where such a HS is merely a «figure head» and fulfills only a symbolic function are excluded. This selective criterion allows Blondel to identify two types of dual executive: the «dual monarchies», as in the cases of Great Britain and Sweden before the decline of the executive functions of their monarchs during the XIX century; and the «semi-presidential republics» in the contemporary world (i.e. French V Republic). Therefore, some formally dual executives generate only an apparent executive dualism, because the executive functions of the HS are very limited or atrophied.

\subsubsection{Procedural resources}

Most IPP and related checklists are based on the listing of the «constitutionally relevant powers», according to Duverger's suggestion. However, this listing cannot be considered sufficient for two related reasons. Firstly, the Constitution of a country is only one, albeit an extremely central one, of the many formal documents and provisions that may regulate the working of an institutional setting. A Constitution provides the general framework according to which the relationships among the roles of authority are arranged but at the same time many other «fundamental norms» may exist and be currently used by them, i.e. standing orders, internal organizational regulations and similar. Secondly, there is another and more acknowledged reason to go beyond the powers listed in a written constitution, which is the likelihood that the formalized and written norms in the Constitution may be substituted or integrated by «regularized practices». This is why the more extensive concept of «procedural 
resource» is here preferred to that of «constitutionally guaranteed power». The procedural resources may be formalized norms to be found in Constitutions, Fundamental Laws, Acts and similar, and/or behaviours and precedents which became «regularized practices» (Friedrich 1950), that have the bindingness of «norms» accepted and obeyed by the roles' incumbents.

A simple method of measuring the relative strength of the institutional roles could be conceived by counting the procedural resources (norms and/or regularized practices) attached to each role on each distinctive relational dimension, within a distinctive arena of confrontation, as schematically shown in Fig. 1. Assuming that the procedural resources have an impact on ability and decisiveness, the more the procedural resources are controlled by a given role, and the more autonomous its action from the potential counteraction of other roles encompassed in the given arena of confrontation, the stronger that role is. The synthesis IPP would be thus replaced by multiple measurements of the relative strength of each institutional role in terms of controlled procedural resources on the various relational dimensions, within a given arena of confrontation. ${ }^{10}$

One of the main faults in the treatment of the institutional arrangements of democratic regimes is the overlooking of the distribution of «procedural resources» among the institutional roles and, therefore, among their actual incumbents. The classifications by Loewenstein $(1957)$ and Steffani $(1979 ; 1983 ; 1995)$ are guilty of this, since the dichotomy of integration versus cooperation of executive and legislature that they adopt is not based on any direct measurement of the distribution of the procedural resources among the institutional roles of authority, nor on any direct interest in their relative spheres of action. In presidential systems, HS and P cooperate because their procedural resources are attributed to separate spheres, respectively the executive and the legislative. No interference is the «efficient secret» of the presidential institutional design, and cooperation between the two powers is needed for the actual working of the institutional machinery. In parliamentarian systems, $\mathrm{G}$ and P occupy the same arena, their spheres of action overlap and the distribution of the procedural resources between them favors their reciprocal interference and the integration of their actions. Varying attributions of procedural resources may hence generate different forms of democratic government.

In Table 2 four ideal typical distributions of procedural resources between HG and HS are introduced. Combination 1, according to which both HG and HS enjoy considerable resources, captures a hypothetical dual structure of the executive, as pointed out by Blondel (1984). In combinations 2 and 3 one of the two roles proves rather marginal in the institutional circuit, and therefore these two combinations can be treated as examples of apparent dual structures of the executives. In such cases, it could be confidently assumed that the structure of the executive is actually monocratic. Finally, combination 4 illustrates apparent dual structures too, because neither HG nor HS control salient procedural resources and the structure of the executive results a-cephalous or collegial.

\footnotetext{
${ }^{10}$ On these bases, a similar measurement of the procedural resources and treatment of the concept of institutional equilibrium has been operationalized and developed elsewhere (Ieraci 2003, 2010)
} 
Table 2 Distribution of the Procedural Resources between the Individual Roles of Authority in the Dual Executives
Distribution of the procedural resources between

Head of the Gov- Head of the ernment (HG) State (HS)

\begin{tabular}{|c|c|c|c|}
\hline 1. & High & High & Dual executives \\
\hline 2. & Low & High & Apparent dual \\
\hline 3. & High & Low & $\begin{array}{l}\text { executives (de } \\
\text { facto Monocratic) }\end{array}$ \\
\hline 4. & Low & Low & $\begin{array}{l}\text { Apparent dual } \\
\text { executives (de } \\
\text { facto Collegial or } \\
\text { acephalous) }\end{array}$ \\
\hline
\end{tabular}

Table 3 Distribution of the Procedural Resources between the Collegial Roles of Authorities

\begin{tabular}{llll}
\hline \multicolumn{4}{l}{ Distribution of the procedural resources between } \\
\cline { 2 - 4 } & Government $(\mathrm{G})$ & Parliament $(\mathrm{P})$ & Balanced \\
1 & High & High & Balanced \\
2 & Low & Low & Unbalanced toward the government \\
3 & High & Low & Unbalanced toward the parliament \\
\hline
\end{tabular}

Similarly, the distribution of procedural resources between $\mathrm{G}$ and $\mathrm{P}$ can be submitted to an empirical analysis, as shown by Table 3. Blondel (1973) underlined that the formal distinction between parliamentary and presidential systems does not contribute to our understanding of the actual relation between executive and legislature. In some cases the supremacy of the executive is guaranteed, in other cases the parliament has the capacity to contest such supremacy to the point of putting the executive at the mercy of the legislature. Following these suggestions, it would be appropriate to distinguish (see Table 3):

- balanced distributions of the procedural resources between $G$ and $P$ (combinations 1 and 2), in which these two collective roles interact on the base of a relative equivalence of strength;

- unbalanced distributions of the procedural resources in favor of $G$ over $\mathrm{P}$ (combination 3);

- finally, unbalanced distributions of the procedural resources in favor of $P$ over $\mathrm{G}$ (combination 4). 


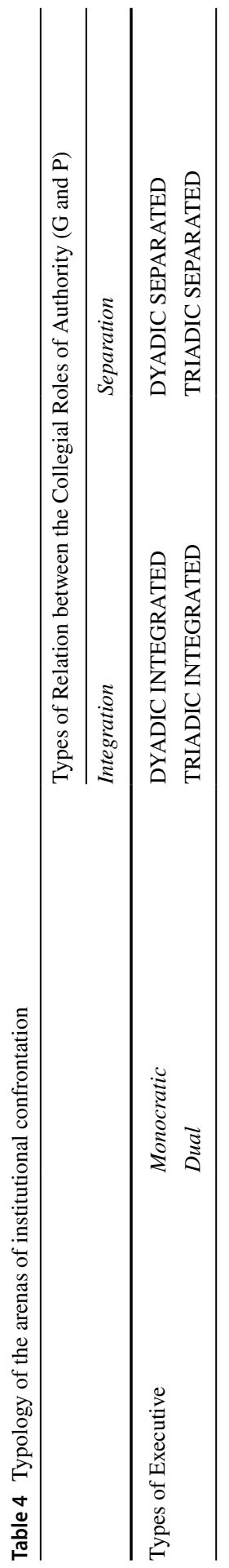


Table 5 Multi-dimensional classification of the forms of the democratic government

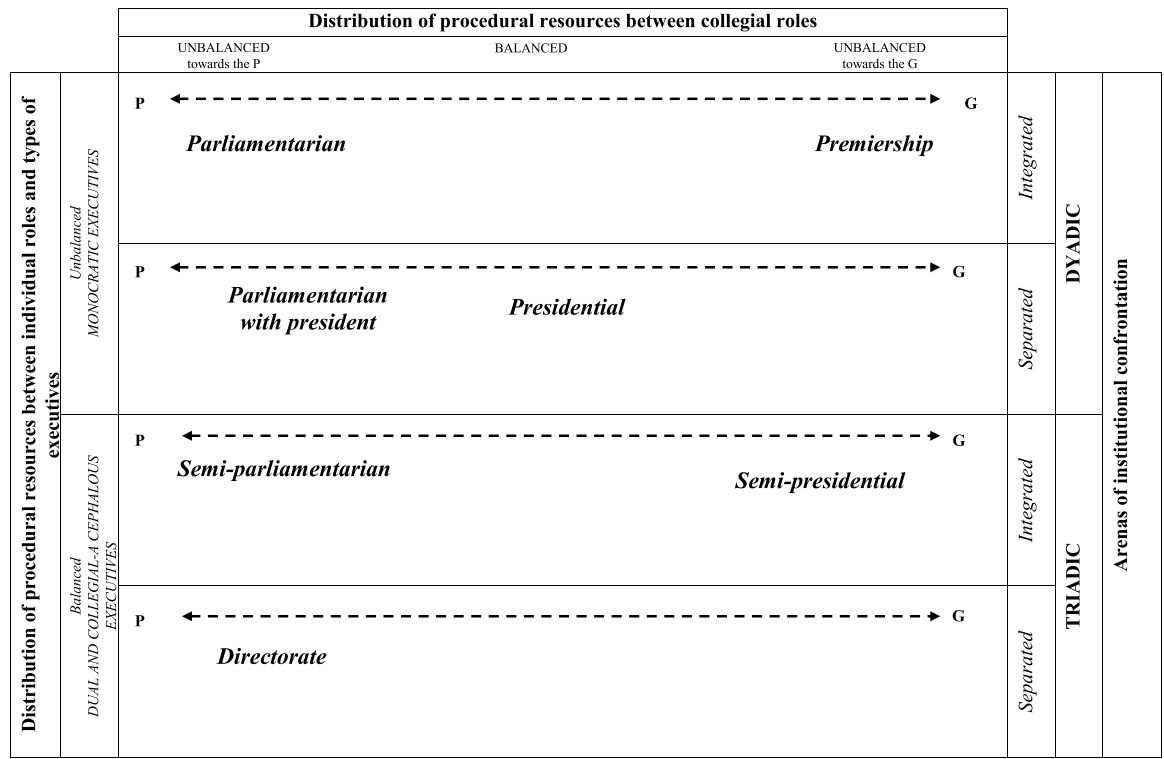

P, Parliament (Legislature); G, Government (Executive)

\subsubsection{Arenas of the institutional confrontation}

The distributions of the procedural resources among the roles are arranged in various arenas of the institutional confrontation (see again Fig. 1). Within each arena, the institutional roles of authority interact, using the procedural resources available to them in order to exercise influence over the institutional decision-making. Assuming two collegial roles, $\mathrm{G}$ and the $\mathrm{P}$, and two individual roles, HG and HS, four distinct arenas of the institutional confrontation can be identified, as shown in Table 4.

The classification of the arenas of the institutional confrontation in Table 4 rests on two criteria, the type of relation between the collective roles of authorities ( $\mathrm{G}$ and P) and the type of executive.

With regard to the type of relation between $\mathrm{G}$ and $\mathrm{P}$ (the two main collective roles to be found in democracy), it has been argued above that it may be based either on integration or separation, as highlighted by the formal approaches of Loewenstein (1957) and Steffani (1979; 1983; 1995). When integrated, G and P work together as two mutually dependent bodies, wheras when they are separated they are independent from each other and are forced to co-operate. Similarly, the typology put forward by Shugart and Carey (1992) employed the criterion of the separation of the survival of $G$ (i.e. executive) from $P$ (i.e. assembly). Therefore when the survival of $G$ depends on the survival of $\mathrm{P}$, the likelihood of a legislature dissolution followed by the fall of the government-or vice versa-is very high. With regard to the second criterion of classification (type of executive), as previously argued, it is possible to detect monocratic and dual executives. 
In Table 4 the two classifying criteria are combined to generate four arenas of institutional confrontation. The dyadic arenas are essentially structured on two roles ( $\mathrm{G}$ and $\mathrm{P}$ or $\mathrm{P}$ and HS), while the triadic arenas are characterized by the presence of a third role, and sometimes even of a fourth role (G, P, HG and/or HS), which leads to multilateral patterns of relations. Hence the four arenas of institutional confrontation may be:

Dyadic and integrated, in which $\mathrm{G}$ and $\mathrm{P}$ are integrated, as previously clarified, while HG and HS are absent or one of these two roles occupies a marginal position in the institutional circuit (the executive is monocratic or the dualism is apparent);

Dyadic and separate, in which the executive is still monocratic or the dualism is apparent, but the $\mathrm{G}$ is not selected by the $\mathrm{P}$, neither is their survival reciprocally linked ( $\mathrm{G}$ and $\mathrm{P}$ are therefore separated, as previously clarified);

Triadic and integrated, in which $\mathrm{G}$ and $\mathrm{P}$ are integrated, and there is a third relevant role of authority, such as a HS and the structure of the executive is dual;

Triadic and separate, in which $\mathrm{G}$ and $\mathrm{P}$ are separate, and there is a third relevant role of authority, such as a HS and the structure of the executive is dual.

\section{Conclusions}

A multidimensional classification obviously generates ideal types and not precise descriptions of the reality. The varieties encountered in the institutional design of contemporary democracies are shown in synthesis in Table 5, which is a classificatory map based on the combination of the selected criterions. The characteristics of the executive structure (monocratic, dual, and collegial/acephalous) lie along the left vertical axle of Table 5. These characteristics are combined with the distributions of the procedural resources between $\mathrm{P}$ and $\mathrm{G}$ along the horizontal axle of Table 5, and are distinguished as either balanced or unbalanced distribution. Finally, these two dimensions of analysis are connected to the four arenas of the institutional confrontation, dyadic integrated and separate, triadic integrated and separate, in order to identify seven different varieties of democratic governments gathered into four main patterns:

Dyadic integrated pattern:

1. Parliamentarian;

2. Premiership.

Dyadic separate pattern:

3. Presidential;

4. Parliamentarian with president.

Triadic integrated pattern:

5. Semi-parliamentarian;

6. Semi-presidential.

Triadic separate pattern:

7. Directorate 
In the classification schema of Table 5, the cases are not rigidly fixed and they can 'float' according to the historical phase and the contingencies. For instance, a case whose institutional setting originally resembled a Parliamentarian model of democracy may undergo a political crisis, G may reinforce gradually its positions vis á vis $\mathrm{P}$, both because of the introduction of new procedural resources at the disposal of the $\mathrm{G}$ or because of new practices established and accepted. This case would gradually shift towards the Premiership pole, and similar considerations can be extended to all the institutional patterns identified by the classificatory schema. Its usefulness and appropriateness is that it allows an appreciation of the constitutive changes of the cases in historical perspective, which cannot be done by fixing them in rigid models. The potential combinations of the institutional design properties allowed by the schema are countless. Therefore, it is not reductive in its intentions but rather its aim is mainly the improvement of the analytical knowledge of the democratic machinery. Nevertheless, at the same time it aims at offering some more sophisticated conceptual tools in order to favor a deeper comprehension of the trade-off between institutions and democratic performance, which would go beyond the plain counter positioning of «Parliamentarian» and «Presidential» models.

Although each pattern is represented as a continuum, the seven varieties should be therefore conceptualized as ideal types and as we know from Weber, ideal types should not be confused with reality. The actual distribution of the cases in the schema of Table 5 are therefore to be verified through an empirical investigation (Ieraci 2003; 2010). The dyadic integrated pattern is characterized by the bilateral relation $\mathrm{P}-\mathrm{G}$, either unbalanced toward the former (parliamentarian) or the latter (premiership). In the parliamentarian type the powers of the legislature overwhelm the cabinet, which encounters difficulties in defending its own policies and very often is forced to compromise with the opposition parties over legislative decisionmaking. In the parliamentarian regimes the cabinets are weak and might lack any clear majority, therefore ending at the mercy of the parliamentary party groups. This condition may produce government instability, and it is obviously exacerbated the more the party system is fragmented. The Italian parliamentarianism is a good example of this type. On the other hand, in the premiership type the cabinet is the «efficient secret» (Bagehot 1963 (but 1867)) of the system. The procedural resources held by the cabinet in the parliamentary arena are such to make it easy for the cabinet to defend its own policies. The cabinet does not compromise with the oppositions over the legislative decision-making, thanks to its strength and its secure and clear parliamentary majority. The main parliamentary party groups tend to coincide with the parliamentary majority on the one hand and with the parliamentary opposition on the other, and this condition fosters the cabinet stability. British parliamentarianism is a good example of this type.

The dyadic separated pattern is still based on the relationship P-G, although the two institutions are not reciprocally bound and $G$ is not under any direct influence exercised by $\mathrm{P}$. In two notable versions of this pattern (presidential and the parliamentarian with president), $\mathrm{G}$ is indeed an institutional «reserve» of the HS to the point of not being recognizable if not as an instrument of the presidential action. The relationship between $\mathrm{G}$ and $\mathrm{P}$ is here less dichotomous and clearly cut than in the previous pattern. In Israel, according to the 1992 institutional reform, the elective 
Table 6 Institutional Patterns, Varieties, and Cases

\begin{tabular}{|c|c|c|c|}
\hline Patterns & Varieties & & Cases \\
\hline \multirow[t]{4}{*}{ Dyadic integrated } & Parliamentarian & Monocratic executives & $\begin{array}{l}\text { Denmark } \\
\text { Italy } \\
\text { Belgium } \\
\text { Hungary } \\
\text { Netherlands } \\
\text { Czech Republic } \\
\text { Norway } \\
\text { French IV Republic } \\
\text { Germany } \\
\text { Sweden }\end{array}$ \\
\hline & & $\begin{array}{l}\text { Apparent dual execu- } \\
\text { tives (Parliamentar- } \\
\text { ian-monocratic de } \\
\text { facto) }\end{array}$ & $\begin{array}{l}\text { Slovakia } \\
\text { Slovenia } \\
\text { Austria }\end{array}$ \\
\hline & Premiership & Monocratic executives & $\begin{array}{l}\text { United Kingdom } \\
\text { Spain } \\
\text { Greece }\end{array}$ \\
\hline & & $\begin{array}{l}\text { Apparent dual execu- } \\
\text { tives (Premiership- } \\
\text { monocratic de facto) }\end{array}$ & $\begin{array}{l}\text { Ireland } \\
\text { Iceland }\end{array}$ \\
\hline \multirow[t]{2}{*}{ Dyadic separate } & Presidential & & $\begin{array}{l}\text { Usa } \\
\text { Argentina (1853 and 1993) } \\
\text { Chile }\end{array}$ \\
\hline & Parliamentarian with president & & Israel (1992) \\
\hline \multirow[t]{2}{*}{ Triadic integrated } & Semi-parliamentarian & & $\begin{array}{l}\text { Finland } \\
\text { Portugal (1982) } \\
\text { Poland } \\
\text { Bulgaria } \\
\text { Croatia (2000) }\end{array}$ \\
\hline & Semi-presidential & & $\begin{array}{l}\text { Republic of Weimar } \\
\text { Portugal (1976) } \\
\text { Russian Federation } \\
\text { French V Republic } \\
\text { Romania } \\
\text { Croatia (1990) }\end{array}$ \\
\hline Triadic separate & Directorate & & Switzerland \\
\hline
\end{tabular}


Prime Minister would choose the ministers of the cabinet, although the legislature could withdraw its confidence and bring about the resignation of the Prime Minister and cabinet and the dissolution of the legislature itself. In turn, the elective Prime Minister had the power to dissolve the legislature and call new elections, but the legislature could deliberate its self-dissolution by a simple majority vote. This complicated system of checks and balances was supposed to generate a virtuous institutional equilibrium, but in fact determined a permanent political conflict between $\mathrm{P}$ and $\mathrm{G}$, and the direct election of the Israeli Prime Minister was abolished in 2001.

The main pitfall of the Israeli constitutional experiment lay in the contradictory attribution of powers to the formally separated G and P. The U.S. presidential model does not allow the legislature and the executive to interfere with each other's survival and the two powers are neatly separated. This separation is the effective guarantee of an institutional balance, which has been rarely acquired by other presidential systems. In the Latin American continent the U.S. presidential model has been very influential, but in its imitations the executive powers have been extended into the legislative sphere through the attribution of decree powers to the Presidents (Carey and Shugart 1998). Moreover, as in the Argentinian and Chilean cases, the administrative centralization has reinforced the presidential prerogatives.

Finally, if we leave apart the Swiss directorate as a peculiar form of the triadic separate government, multilateral relationships among the institutional roles are disclosed in the triadic integrated pattern. In the semi-parliamentarian and semi-presidential systems, $\mathrm{G}$ and $\mathrm{P}$ are indeed integrated in a distinct arena of confrontation, and a difference can be traced between those types featuring relevant executive and legislative powers (semi-presidential systems) or limited executive and legislative powers (semi-parliamentarian systems). As already stated, the distinction between semi-parliamentarian and semi-presidential systems is designed to iclude a variety of cases. The French V Republic and the Weimar Republic, both characterized by a strong popularly elective presidency, are very different from the homologous semipresidential regimes of Finland and Portugal, while Ireland and Austria, among others, are only apparent dual executives. ${ }^{11}$

Table 6 summarizes the proposed classification linking appropriately 34 cases to the four institutional patterns and relative varieties. The picture derived is rather complex, but this was not unintentional. From the first column on the left to the last on the right, Table 6 moves from the general criteria of classification to the cases. The classification fulfils two goals. Firstly, it could be used as a description of the variety of institutional designs in democracy. It is a deeper look into democratic institutions because it goes far beyond the easy dichotomy between parliamentarism and presidentialism of the constitutional approach. Secondly, the suggested classification could be used as a prescriptive guide to institutional design as well.

\footnotetext{
11 Similarly Siaroff (2003, 307-308) distinguished among «parliamentary systems with presidential dominance» (i.e., France V Republic, Russia), «parliamentary systems with a presidential corrective» (i.e., Weimar Republic, Poland), and «parliamentary systems with figurehead presidents» (i.e., Austria, Iceland, Slovenia, Finland since 2000). Nonetheless, the latter type identify cases which are here considered as «apparent dual executives» (see Table 2), and therefore they are not included in the "semipresidential" varieties.
} 
Very often the debate over institutional reform of a democracy is carried on with little or no consideration of its true implication in terms of institutional equilibrium. Therefore normally the advocacy of the "strong government" faces the advocacy of the "parliament centrality" in an ideological struggle. Nonetheless, Parliaments and Governments, Presidents and Prime Ministers are all part of an overall framework of relationships, which offers endless opportunities for solutions and equilibria. To explore them we need a much more complex map of the institutional design.

Funding Open access funding provided by Università degli Studi di Trieste within the CRUI-CARE Agreement.

Open Access This article is licensed under a Creative Commons Attribution 4.0 International License, which permits use, sharing, adaptation, distribution and reproduction in any medium or format, as long as you give appropriate credit to the original author(s) and the source, provide a link to the Creative Commons licence, and indicate if changes were made. The images or other third party material in this article are included in the article's Creative Commons licence, unless indicated otherwise in a credit line to the material. If material is not included in the article's Creative Commons licence and your intended use is not permitted by statutory regulation or exceeds the permitted use, you will need to obtain permission directly from the copyright holder. To view a copy of this licence, visit http://creativecommons.org/licen ses/by/4.0/.

\section{References}

Bagehot, W. (1963, 1st ed. 1867). The English constitution. Glasgow, Fontana-Collins.

Bahro, H., Bayerlein, B., \& Veser, E. (1998). Duverger's concept: semi-presidential government revisited. European Journal of Political Research, 34, 201-224.

Blondel, J. (1973). Comparative legislatures. Englewood Cliffs: Prentice-Hall Inc.

Blondel, J. (1984). Dual leadership in the contemporary world: A step towards executive and regime stability. In D. Kavanagh \& G. Peele (Eds.), Comparative government and politics. Essays in honour of S.E Finer (pp. 73-91). London: Heineman.

Carey, J. M., \& Shugart, M. S. (Eds.) (1998). Executive decree authority. Cambridge: Cambridge University Press.

Duverger, M. (1978). Échec au roi. Paris: Albin Michel.

Duverger, M. (1980). A new political system model: Semi-presidential government. European Journal of Political Research, 8, 165-187.

Duverger, M. (1986). Les régimes semi-présidentieles. Paris: Presses Universitaires de France.

Elgie, R. (1997). Models of executive politics: A framework for the study of executive power relations in parliamentary and semi-presidential regimes. Political Studies, 45(2), 217-231.

Elgie, R. (1998). The classification of democratic regime types: Conceptual ambiguity and contestable assumptions. European Journal of Political Research, 33, 219-238.

Elgie, R. (1999). The politics of semi-presidentialism. In R. Elgie (Ed.), Semi-presidentialism in Europe (pp. 1-21). Oxford: Oxford University Press.

Elster, J. (1997). Afterword: The making of postcommunist presidencies. In R. Taras (Ed.), Postcommunist Presidents (pp. 225-237). Cambridge: Cambridge University Press.

Fabbrini, S., \& Vassallo, S. (1999). Il governo. Gli esecutivi nelle democrazie contemporanee. Roma: Laterza.

Friedrich, C. J. (1950). Constitutional government and democracy. Boston: Ginn and Company.

Frye, T. (1997). A politics of institutional choice. Post-Communist presidencies. Comparative Political Studies, 30, 523-552.

Ieraci, G. (2003). Teoria dei governi e democrazia. Ruoli, risorse e arene istituzionali. Bologna: Il Mulino. 
Ieraci, G. (2010). Presidenti, governi e parlamenti: analisi comparata delle istituzioni di vertice in 27 democrazie contemporanee. Trieste: EUT Edizioni Università di Trieste.

Linz, J. J. (1994). Presidential or parliamentary democracy: Does it make a difference? In J. J. Linz \& A. Valenzuela (Eds.), The failure of presidential democracy (pp. 3-87). Baltimore-London: The Johns Hopkins University Press.

Lijphart, A. (1999). Patterns of democracy government forms and performance in thirty-six countries. New Haven: Yale University Press.

Loewenstein, K. (1957). Political power and the governmental process. Chicago: The University of Chicago Press.

Mainwaring, S., \& Shugart, M.S. (Eds.) (1997). Presidentialism and democracy in Latin America. Cambridge: Cambridge University Press.

McGregor, J. (1994). The presidency in east central europe. RFE/RL Research Report, 3, $23-31$.

Metcalf, L. K. (2000). Measuring presidential power. Comparative Political Studies, 33, 660-685.

Sartori, G. (1994a). Neither presidentialism nor parliamentarism. In J. J. Linz \& A. Valenzuela (Eds.), The failure of presidential democracy (pp. 106-118). Baltimore-London: The Johns Hopkins University Press.

Sartori, G. (1994b). Comparative constitutional engineering: An inquiry into structures, incentives and outcomes. London: Macmillan.

Shugart, M. S., \& Carey, J. M. (1992). Presidents and assemblies. Constitutional design and electoral dynamics. Cambridge: Cambridge University Press.

Siaroff, A. (2003). Comparative presidencies: The inadequacy of the presidential, semipresidential and parliamentary distinction. European Journal of Political Research, 42, 287-312.

Steffani, W. (1979). Parlamentarische und präsidentielle Demokratie. Strukturelle Aspekte westlicher Demokratien. Opladen: WestdeutscherVerlag.

Steffani, W. (1983). Zur Unterscheidung parlamentarischer und präsidentieller Regierungsssysteme. ZeitschriftfürParlamentsfragen, 3, 390-401.

Steffani, W. (1995). Semi-Präsidentialismus: eineigenständiger Systemtyp? Zur Unterscheidung von Legislative und Parlament. Zeitschrift für Parlamentsfragen, 4, 621-641.

Stepan, A., \& Skach, C. (1994). Presidentialism and parliamentarism in comparative prespective. In J. J. Linz \& A. Valenzuela (Eds.), The failure of presidential democracy (pp. 119-136). BaltimoreLondon: The Johns Hopkins University Press.

Van Cranenburgh, O. (2008). Big men rule: presidential power, regime type and democracy in 30 African countries. Democratization, 15(5), 952-973.

Vatter, A. (1999). Lijphart expanded: three dimensions of democracy in advanced oecd countries? European Political Science Review, 1(01), 125-154.

Zulianello, M. (2011). I poteri delle istituzioni di vertice in democrazia. Problemi di misurazione e di metodo nell'analisi degli esecutivi duali. Quaderni di Scienza Politica, XVIII, 2, 293-318.

Publisher's Note Springer Nature remains neutral with regard to jurisdictional claims in published maps and institutional affiliations. 